\title{
LANGUAGE LEARNING STRATEGIES USED BY SUCCESSFUL STUDENTS OF THE ENGLISH EDUCATION STUDY PROGRAM AT UNIVERSITY OF BENGKULU
}

\author{
Purnama Yulian Sari \\ Universitas Bengkulu \\ purnama.yulians@yahoo.com \\ Dedi Sofyan \\ Universitas Bengkulu \\ dedisofyan73@gmail.com \\ Gita Mutiara Hati \\ Universitas Bengkulu \\ gitawitanto@gmail.com
}

\begin{abstract}
ABSTRAK
Penelitian ini bertujuan untuk mengetahui strategi belajar Bahasa yang digunakan oleh mahasiswa sukses yang di kategorikan dalam enam tipe strategi yaitu: memori, kognitif, kompensasi, metakognitif, afektif, dan sosial strategi berdasarkan teori Oxford (1990). Populasi penelitian ini adalah mahasiswa jurusan pendidikan Bahasa Inggris, Universitas Bengkulu angkatan 2014 dan 2015 yang memiliki IPK 3.51 sampai dengan 4.00. Metodologi penelitian yang digunakan adalah deskriptif kuantitatif. Data dikumpulkan dengan menggunakan kuesioner sebagai instrument untuk mengetahui data. Kuesioner terdiri dari 50 item berdasarkan Oxford's Strategy Inventory for Language Learning (SILL) versi 7.0 tentang strategi belajar Bahasa. Data tersebut diproses dengan menggunakan Microsoft Excel 2013 untuk mengetahui strategi mana yang paling banyak digunakan oleh mahasiswa sukses. Hasil penelitian ini menunjukan bahwa mahasiswa sukses menggunakan campuran strategi pembelajaran Bahasa, termasuk memori, kognitif, kompensasi, metakognitif, afektif, dan sosial strategi. Untuk strategi yang paling banyak digunakan oleh mahasiswa sukses adalah metakognitif strategi dengan skor mean (3.94) diikuti dengan kompensasi (3.81), kognitif (3.59), sosial (3.43), memori (3.31), dan afektif strategi (3.30). strategi-strategi metakognitif mempunyai pengaruh yang positif dan signifikan terhadap prestasi akademik pada mahasiswa sukses dalam belajar Bahasa. Strategi metakognitif dapat membantu mengembangkan kemampuan manajemen berpikir yang baik sehingga menunjukan prestasi akademik yang baik pula. Di sisi lain, pilihan strategi terendah dapat dipengaruhi oleh kemajuan teknologi, kurikulum, perasaan, suasana hati, dan sikap dari mahasiswa yang sulit dipresiksi.
\end{abstract}

Kata kunci: strategi belajar bahasa, siswa sukses 


\begin{abstract}
This research is aimed at finding the language learning strategy used by successful students that is categorized into six kinds of strategies; memory, cognitive, metacognitive, affective, compensation, and social strategy suggested by Oxford (1990). The population of the research are students of English study program University Bengkulu year 2014 and 2015 that have GPA 3.51 to 4.00 . Methodology of this research is descriptive quantitative. Data were collected by using questionnaires as the instruments. The questionnaires consist of 50 items based on Oxford's Strategy Inventory for Language Learning (SILL) version 7.0 about language learning strategy. The data were processed by using Microsoft Excel 2013 to find the most dominant strategy used by the students. The results showed that the successful students use more than one language learning strategy or mixed strategy, including memory, cognitive, metacognitive, affective, compensation, and social strategy. The dominant strategy used by successful students was metacognitive with mean score 3.94 followed by compensation (3.81), cognitive (3.59), social (3.43), memory (3.31), and affective strategy (3.30). Metacognitive strategies have positive and significant influence toward academic achievement on successful students in learning a language. Metacognitive strategies can help the students to develop good thinking management ability. It also create good academic achievement. In the other hand, the choice of lowest strategy seems to be affected by technology advances, curriculum, feelings, mood, and attitude of the students which is unpredictable.
\end{abstract}

Keywords: language learning strategy, successful students.

\section{INTRODUCTION}

Nowadays English is known as an international language. To elaborate, most of the population in the world uses English as a way to socialise effectively and create a decent conversation within one to another. Some countries speak English as their second language. However, many others used English as a foreign language, including Indonesia. Most of students in Indonesia have been learning English from a very young age to an adult level. As a foreign language, learning another language such as English is very difficult thing to do.

English have four skills that students should be mastered, there are listening, speaking, reading, and writing. In listening, the student must be able to hear a new item (sound, word, grammar feature, etc.). In speaking, the student has to try to repeat a word or a sentence in order to successfully deliver an item. In reading, the student sees the new item in a written form. In writing, the student must produce the written form using the item.

In English Education Study Program of FKIP UNIB, the students are expected to use English as well. That is because the students are trained to be a teacher in the future. As a teacher, they should know and have a good knowledge and skills in English. If all these elements are successfully to be used, the students surely and will easily have an understanding in English language. However, learning English as a foreign language is not as easy for students to master. To avoid the difficulties, the learners 
need a learning strategies in order to master it well.

According to Oxford (1990, p. 8) learning strategies are specific actions taken by learners to help their own learning, to make the learning easier, faster, more enjoyable, more self-directed, more effective and more transferable, the students should know what learning strategies are suitable for them to master the skill. Every student has a different style and strategies to acquire the skill. According to Cohen (1998: 4) defines learning strategies as learning process which are consciously selected by the learner.

Oxford (1990) identified learning strategies between direct and indirect strategies. Direct strategies require mental processing of the target language. There are three main groups of direct strategies: memory strategies, cognitive strategies and compensation strategies. Each group processes the language differently and for different purposes. Indirect strategies, on the other hand, support and manage language learning often without involving the target language directly. There are three groups of indirect strategies: metacognitive strategies, affective strategies and social strategies. Oxford's classification has been selected for this study.

Some previous studies about learning strategies are comparing the successful students with unsuccessful students in one class or comparing the learning strategies based on academic levels in using the strategies. The study from Lestari (2015) about Language Learning Strategies of English Education Department of FITK take the subject by the students of English Education Department in UIN Syarif Hidayatullah Jakarta which pursue in the fourth semester and sixth semester. They were chosen based on their different academic levels. There are sixty students from the Department of English Education that are divided into thirty students for each semester. The result of the study reveals the FITK students used all learning strategies, including memory, cognitive, compensation, metacognitive, affective and social. For the most frequently used by the students of the fourth semester students and the sixth semester students is metacognitive strategy. Whereas, the least frequently used by the 4th semester students is memory strategy and by the 6th semester is social strategy.

Other studies just did the test or examine some strategies for successful or unsuccessful students. In Language Learning Strategies Used by Successful and Unsuccessful Iranian EFL Students by Geramia and Baighloub (2011), the study examines the application of language learning strategies by successful and unsuccessful Iranian EFL students. To do so, memory, cognitive, compensation, metacognitive, affective and social language learning strategies were investigated. The results of this study can be beneficial for Iranian language teachers in terms of raising their awareness on narrowing the gap between the students' language learning strategies and their teaching methodologies preferences. From some previous studies, the title mention about language learning strategies and successful students, but they did not explain actually in detail about the language learning strategies that the successful students have or used.

The above explanation becomes the researcher's background in proposing this research. The researcher would like to know and identify the language learning strategies used by successful students of the English Education Study Program University of Bengkulu.

\section{METHOD}

This research used descriptive quantitative method to answer the questions of the 
study because the gathered data will be described in form of number. Johnson \& Christensen (2004) stated that quantitative research was kind of research that relies on the collection of quantitative data. The form of report is in statistical form.

The researcher used this kind of method because to collect the data, Likert-scale questionnaire is used. The data collected from the questionnaire is analyzed using statistical analysis and a formula is used to identify the data.

The population of this research are students from English Education Study Program University of Bengkulu, semester 6 and 8 from 2014 and 2015 generation. This research used purposive sampling. According to Arikunto (2010:183), purposive sampling is the process of selecting sample by taking subject that is not based on the level or area, but it is taken based on the specific purpose. The sample of this research is the students who have GPA 3.51 until 4.00 there are 43 students as described in the following table.

Table 1. The Distribution of Subject

\begin{tabular}{|c|c|c|}
\hline No & Semester & Number of Students \\
\hline 1 & 6 & 21 \\
\hline 2 & 8 & 22 \\
\hline \multicolumn{2}{|c|}{ Total } & 43 \\
\hline
\end{tabular}

In this study, the researcher used questionnaire as an instrument. Questionnaire is a set of statement in written form to gather information from the respondents of the research. The instrument of this research is questionnaire based on Oxford's Strategy Inventory for Language Learning (SILL) version 7.0. Questionnaire were translated into Bahasa Indonesia in order to make them easier to be understood and to avoid misinterpretation. The SILL questionnaire is designed to assess language learning strategy use. In the SILL, language learning strategies grouped into six categorized of assessment: (a) memory strategies (9 items) which represent to remembering effectively, (b) cognitive strategies (14 items) which represent using mental process, (c) compensation strategies (6 items) which represent compensating for missing knowledge, (d) metacognitive strategies (9 items) which represent organizing and evaluating the learning, (e) affective strategies (6 items) which represent managing emotion, and ( $f$ ) social strategies (6 items) which represent learning with others. (Oxford, 1990, pp. 293-300).

Before distributing the questionnaire, the researcher does some preparation. The questionnaire was checked to certain that there are no confusing words or phrase which may be encountered by the respondents. The researcher used Bahasa Indonesia in order to make the students easier to be understood. Then, the questionnaire was copied as many as the number of the students. After the questionnaire is ready to be administrated, the researcher came upon the students to collect the data. The last step in this research is to analyze the data that has been collected.

The formulas used in analyzing the data were using mean and percentage as follows:

1. Mean

$$
\begin{array}{|l}
\hline \bar{X}=\frac{\sum X}{N} \\
\bar{X} \quad: \text { mean } \\
\sum X \quad: \text { sum of all data values } \\
N \quad \text { : number of data items. }
\end{array}
$$

\section{Percentage}

$$
\begin{array}{ll}
\hline P= & \frac{F}{N} \times 100 \\
P & : \text { percentage } \\
F \quad: \text { frequency of responses } \\
N \quad: \text { number of respondents }
\end{array}
$$

To determine the use of learning strategies by successful students, the researcher used Oxford's (1990) rating scheme for strategy use. The rating scheme 
is 1.0 to 2.4 which shows low, 2.5 to 3.4 which shows moderate, and 3.5 to 5.0 which shows high level of strategy use.

Table 2. Rating Scheme for Strategy Use

\begin{tabular}{|c|c|}
\hline Mean & Category \\
\hline $1.0-2.4$ & Low \\
\hline $2.5-3.4$ & Moderate \\
\hline $3.5-5.0$ & High \\
\hline
\end{tabular}

\section{RESULT}

In this section, the researcher presents the result of the research that has been conducted. The result is divided into six types of language learning strategies used by successful students.

First, the total average of the mean score for memory strategies use was 3.31 which is categorized as "Moderate". It indicated that students were usually use memory strategies in language leaning.

Second, the total average of the mean score for cognitive strategies use was 3.59 which is categorized as "High". It indicated that students were highly use cognitive strategies in language learning.

Third, the total average of the mean score for compensation strategies use was 3.81 which is categorized as "High". It indicated that students were highly use compensation strategies in language learning.

Fourth, the total average of the mean score for metacognitive strategies use was 3.94 which is categorized as "High". It indicated that students were often use metacognitive strategies in language learning.

Fifth, the total average of the mean score for Affective strategies use was 3.30 which is categorized as "Moderate". It indicated that students were sometimes use Affective strategies in language learning.

Sixth, the total average of the mean score for Socio strategies use was 3.43 which is categorized as "Moderate". It indicated that students were sometimes use socio strategies in language learning.

Based on the data obtained from the questionnaire, the table below summarizes the students' use of listening comprehension strategies.

Table 3. Language Learning Strategies Use

\begin{tabular}{|c|c|c|c|}
\hline No & Strategies & Mean & Category \\
\hline 1 & $\begin{array}{c}\text { Memory } \\
\text { Strategies }\end{array}$ & 3.31 & Moderate \\
\hline 2 & $\begin{array}{c}\text { Cognitive } \\
\text { Strategies }\end{array}$ & 3.59 & High \\
\hline 3 & $\begin{array}{c}\text { Compensation } \\
\text { Strategies }\end{array}$ & 3.81 & High \\
\hline 4 & $\begin{array}{c}\text { Metacognitive } \\
\text { Strategies }\end{array}$ & 3.94 & High \\
\hline 5 & $\begin{array}{c}\text { Affective } \\
\text { Strategies }\end{array}$ & 3.30 & Moderate \\
\hline 6 & $\begin{array}{c}\text { Socio } \\
\text { Strategies }\end{array}$ & 3.43 & Moderate \\
\hline
\end{tabular}

Based on the table above, it can be seen that successful students use all the strategies, but there are some differences in the frequency of using those strategies. Cognitive strategies, compensation strategies, and metacognitive strategies use were categorized as "High" with the mean score 3.59 for cognitive strategies, 3.81 for compensation strategies, and 3.94 for metacognitive strategies. While memory strategies, affective strategies and socio strategies use was categorized as "Moderate" with the mean score 3.31 for memory strategies, 3.30 for affective strategies and 3.43 for socio strategies. It can be concluded that successful students use metacognitive strategies most frequently, followed by compensation strategies, cognitive strategies, socio strategies, memory strategies, and the last affective strategies.

\section{DISCUSSION}


From the result in the previous subchapter, it can be seen that the successful students used strategies in language learning, namely; memory, cognitive, compensation, metacognitive, affective and socio strategies in language learning. However, the result showed that the use of those strategies was different.

The result of this study has shown that sudents used metacognitive strategy in "High" predicate. Metacognitive strategies were strategies that include the aspect of planning, monitoring and evaluating in language learning strategies. It also includes person knowledge in this strategy. The term of metacognitive is a knowledge concerning to what is learned or how to learn. Then, it appears an awareness about what is known and what is unknown. If this awareness is occured, then a person is able to begin his thought by planning, monitoring, and assessing what is learned. It is similar to Liu's study in Lestari (2015). He found that the participants of his study preferred using metacognitive strategy the most. The present study support his finding. A possible explanation about why metacognitive become the most preferred strategies because it allows the learners to overview the lesson, to pay attention in the classroom and to self-monitor and self-evaluate the language learning.

Metacognitive strategies have positive and significant influence toward academic achievement on successful students in learning a language. Metacognitive strategies can help to develop good thinking management ability. It also create good academic achievement. According to Livingston (1997) Metacognition refers to higher order thinking which involves active control over the cognitive processes engaged in learning. Activities such as planning how to approach a given learning task, monitoring comprehension, and evaluating progress toward the completion of a task are metacognitive in nature.
Because metacognitive plays a critical role in successful learning, it is important to study metacognitive activity and development to determine how students can be taught to better apply their cognitive resources through metacognitive strategy.

Coutinho (2007) states that there is a positive relationship between academic achievement and metacognitive. Students with good metacognitive abilities will exhibit good academic performance compared with students who have low metacognitive abilities. From the results of this study, it can be interpreted that metacognitive strategy is important and must be owned by all students followed by other strategies.

On the other hand, is the lowest frequently used of strategy this research. Affective strategies were strategies that talking about feelings, mood and anxiety level, managing emotions, motivation, and attitudes toward learning process like using technique to alternate the tense by deep breathing, using music, give reward for themselves etc.

The result of this study has shown that students almost rarely used affective as strategy in learning. According to Sinaga (2012), the learning process and the moral building (affective) have some difficulties. Firstly, the influence of technology advances, particularly the information technology which provides various options of events program and contents in social media that influence children character building. In this age, there are more students express their feelings in social media rather than with their friends or diary. Secondly, the difficulties of controlling students because many factors that can influence development of someone's attitude such as feelings and moods which are often being changed. Thirdly, the successful of building an attitude cannot be evaluated soon. It is different from cognitive or metacognitive aspect building and its skill aspect where the results can be known after 
the learning process ends, therefore the successful of new attitude building can be seen at long time span. Actually, the development of attitude ability (affective) through either the process of application in daily lives or modeling is not only decided by teacher, but also other factors such as family, friends, and environment. Fourthly, all this time, the educational process appropriate with the applicable curriculum tends to be directed for intellectual building (cognitive ability) so the affective ability is often being dismissed.

It is similar to Mullins's study (1992) with ELF learners in Thailand. He found that affective strategies showed a negative link with some measure of L2 proficiency. One reason might be that as some students progress toward proficiency, they no longer need affective strategies as much as before. Perhaps because learners' use of cognitive, metacognitive, and social strategies is related to greater L2 proficiency and selfefficacy, over time there might be less need for affective strategies as learner's progress to higher proficiency.

The result of this research can be used by others as the references for using strategies in language learning. Since the subject of this research was categorized as good in language learning, other students can apply the strategies which have been described from the result before. In applying strategies, there is no guaranteed to follow the steps for every situation. It depends on students' flexibility in the way their learning activities. In addition, language learning strategies are affected by many factors, inside and outside the learners like motivation, planning, and condition of the learners. For the further researcher that will conduct the research in the same field, they can develop this research and use it as the reference.

\section{CONCLUSIONS}

Based on the data analysis and findings above, it can be summarized as follows: (1) The successful students not only used single learning strategy but they used mixed learning strategies including memory, cognitive, compensation, metacognitive, affective and socio strategy. They can be categorized as a high and moderate user of learning strategy. (2) Metacognitive strategy becomes the learning strategy which tended to be dominantly used by successful students in English Education Study Program at University of Bengkulu, followed by compensation strategy, cognitive strategy, socio strategy, memory strategy and affective strategy based on frequency of usage. It is similar to Lestari (2015) and Geramia's (2011) study, that metacognitive strategy become the strategy which tend to be used by the learners.

Therefore, it can be assumed that language learning strategy is one of the requirements of every student to become success in language learning. To enhance students' learning strategy, they are required to practice more about how to use the learning strategy itself. Moreover, students also need to acknowledge their learning strategy to make the learning process effective.

The result of this research can be used by others as the references for using strategies in language learning. Since the subject of this research was categorized as good in language learning, other students can apply the strategies which have been described from the result before. In applying strategies, there is no guaranteed to follow the steps for every situation. It depends on students' flexibility in the way their learning activities. In addition, language learning strategies are affected by many factors, inside and outside the learners like motivation, planning, and condition of the learners. For the further researcher that will conduct the research in the same field, they 
can develop this research and use it as the reference.

\section{SUGGESTION}

In relation to the conclusion, the researcher would like to give some suggestions as follow: (a) For the lecturers and the students, it is advisable to develop and use metacognitive strategy through learning methods that presented in the classroom, such as conceptualizing learning materials and using strategies in accordance with the metacognitive, since the results in this research, metacognitive strategy is the most frequently used by successful students in language learning. (b) The future researchers can use it as a reference to adapt and to develop language learning strategies. The next researcher can try to conduct this research in different subject of skills such as listening, speaking, reading and writing. They also can develop the material based on metacognitive strategy and do the experiment and research in classroom.

\section{REFERENCES}

Arikunto, S. (2006). Prosedur Penelitian: Suatu Pendekatan Praktik. Jakarta. Rineka Cipta.

Cohen, A. D. (1998). Strategies in learning and using a second language. Harlow, Essex: Longman.

Coutinho, S.A. (2007). The Relationship between Goals Metacognition and Academic Success. [Online], from: http://www.educatejournal.org

Geramia, M. H. \& Baighloub, S. M. G. (2011). Language Learning Strategies Used by Successful and Unsuccessful Iranian EFL Students. Iran. Elsevier Ltd.

Johnson, R. B., \& Christensen, L. B. (2004). Educational Research: Quantitative, Qualitative, and Mixed Approach. Boston: Allyn and Bacon.

Lestari, N. O. (2015). Language Learning Strategies of English Education
Department of FITK. Jakarta. UIN Jakarta.

Liu, Dongyue. (2004) "EFL Proficiency, Gender and Language Learning Strategy Use Among a Group of Chinese Technological Institute English Majors." Annual Review of Education, Communication and Language Sciences, Volume 1.

Livingston, J.A. (1997). Metacognition: An

Overview. [Online], from: https://eric.ed.gov/?id=ED474273

Mullins, P., (1992). Successful English Language Learning Strategies of Studets Enroll in the Faculty of Arts, Chulalongkorn University, Bangkok, Thailandd. Unpublished doctoral dissertation, United States International University, San Diego, CA.

Oxford, R. L. (1990 p.8). Language learning strategies: What every teacher should know. New York: Newbury House.

Oxford, R. L., \& Cohen, A. D. (1992). Language learning strategies: Crucial issues of concepts and classification. Applied Language Learning, 3(1-2), 1-35.

Oxford, R. L., \& Judith Burry-Stock (1995). Assessing the use of language learning strategies worldwide with the ESL/EFL version of the Strategy Inventory for Language Learning (SILL), System, 25/1, 1-23

Sinaga, N. I. (2012). Strategi Pembelajaran Afektif. Retrieved on July $16^{\text {th }} 2018$. From: http://indrianynovitasinaga.blogspot. com 